\title{
Rancang Bangun Simulator Sistem SCADA (Supervisory Control And Data Acquisition) Pada Gardu Induk Rawalo
}

\author{
Itmi Hidayat Kurniawan \\ Program Studi Teknik Elektro, \\ Fakultas Teknik dan Sains \\ Universitas Muhammadiyah Purwokerto, \\ Purwokerto, Indonesia \\ itmi.hidayat.kurniawan@gmail.com
}

\author{
Rizki Fauzi Muliarto \\ Program Studi Teknik Elektro, \\ Fakultas Teknik dan Sains \\ Universitas Muhammadiyah Purwokerto, \\ Purwokerto, Indonesia \\ rizkifauzimuliarto@gmail.com
}

\begin{abstract}
Abstrak-Dengan perkembangan teknologi sekarang ini untuk mengontrol dan memonitoring peralatan-peralatan di gardu induk yang lokasinya berjauhan dapat dilakukan dalam satu tempat ruang kontrol dengan menggunakan sistem SCADA (Supervisory Control And Data Acquisition). Penelitian berguna untuk proses pembelajaran serta simulator bagi mahasiswa dan tenaga kerja gardu induk baru yang ingin mempelajari sistem SCADA pada gardu induk. Tujuan penelitian ini untuk membuat sebuah sistem SCADA untuk mengontrol dan mengawasi simulator plant gardu induk, contoh sistem gardu induk yang dikontrol yaitu jalur Transformer 1 dan jalur Transformer 2 yang ada di gardu induk Rawalo. Pada penelitian ini mengunakan tiga PLC Twido untuk mengontrol simulator plant gardu induk, PLC pertama digunakan sebagai master dan dua PLC lainnya digunakan sebagai PLC slave. Pada plant terdapat dua Power Meter PM5350 digunakan untuk mengukur besaran Isitrik seperti arus, tegangan, daya aktif, daya reaktif, daya semu, frekuensi dan faktor daya pada jalur Transformer 1 dan jalur Transformer 2. Dari hasil perancangan dan pengujian diperoleh bahwa PLC Twido dapat digunakan sebagi PLC master dan slave, penggunaan software SCADA Wonderware InTouch dapat memvisualisasikan plant yang dikontrol, menampilkan hasil pengkuran besaran listrik dan mencatat alarm ketika terjadi ganguan. Data hasil pengukuran besaran listrik simulator plant gardu induk disimpan di dalam database Microsoft Access.
\end{abstract}

Kata Kunci-SCADA, PLC, PM5350, Gardu Induk

\section{Pendahuluan}

Dengan perkembangan teknologi sekarang ini untuk mengontrol dan memonitoring peralatan-peralatan di gardu induk yang lokasinya berjauhan dapat dilakukan dalam satu tempat ruang kontrol dengan menggunakan sistem SCADA (Supervisory Control And Data Acquisition). Untuk mempelajari sistem SCADA gardu induk, dalam penelitian ini dijelaskan dan realisasi miniatur perancangan sistem SCADA untuk diterapkan di gardu induk. PLC (Programmable Logic Controller) disimulasikan untuk mengontrol DS (Disconecting Switch) dan CB (Circuit Breaker) serta pembacaan energi listrik gardu induk dilakukan oleh Power Meter PM5350. Penelitian ini berguna untuk proses pembelajaran serta simulator bagi mahasiswa dan tenaga kerja gardu induk baru yang ingin mempelajari sistem SCADA pada gardu induk.
Masalah yang akan dijelaskan dalam penelitian ini adalah bagaimana cara membuat simulator gardu induk berbasis SCADA (Supervisory Control And Data Acquisition) dan menampilkan hasil pengukuran besaran energi listrik simulator gardu induk pada HMI (Human Machine Interface). Bagaimana cara membuat sistem PLC master-slave pada simulator gardu induk dengan menggunakan PLC Twido. Membuat management alarm dan data logger pada simulator gardu induk. Contoh sistem gardu induk yang dikontrol yaitu jalur Transformer 1 dan jalur Transformer 2 yang ada di gardu induk Rawalo.

\section{BAHAN DAN METODE}

\section{A. Gambaran Umum Sistem}

Sistem yang akan dibangun merupakan sistem SCADA simulator gardu induk yang terdiri dari tiga PLC Twido, satu PLC digunakan sebagai master sedangkan dua PLC lainnya digunakan sebagai slave, kedua PLC slave tersebut digunakan untuk mengendalikan plant pada tempat yang berbeda. Pada plant terdapat dua Power Meter yang digunakan untuk membaca nilai pengukuran besaran listrik. Nilai hasil pembacaan Power Meter dibaca oleh PLC slave, yang selanjutnya PLC master membaca nilai tersebut dari PLC slave lalu ditampilkan pada HMI.

Komunikasi Power Meter 1 dan Power Meter 2 ke PLC slave 1 menggunakan komunikasi RS-485, komunikasi PLC slave 2 ke PLC master mengunakan komunikasi RS-485. Sedangkan komunikasi antara PLC slave 1, PLC master dan komputer menggunakan komunikasi ethernet. Dimana data beserta protokol akan dikirim melalui jaringan LAN. Hub pada sistem ini perlu digunakan untuk menyatukan beberapa jaringan ethernet. Gambaran umum perancangan sistem yang dibangun dapat dilihat pada Gambar 1 berikut. 


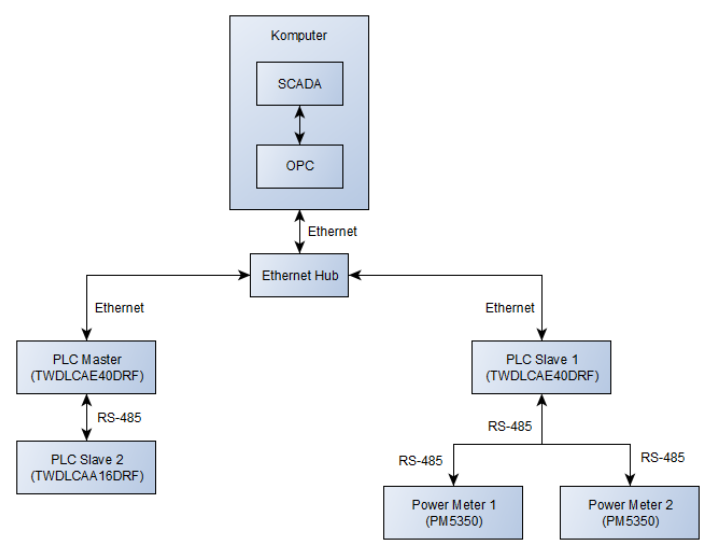

Gambar 1. Gambaran Umum Sistem

B. Diagram Alir Sitem Kendali

Diagram alir (Flowchart) untuk pengendalian simulator plant gardu induk dapat dilihat pada Gambar 2 berikut.
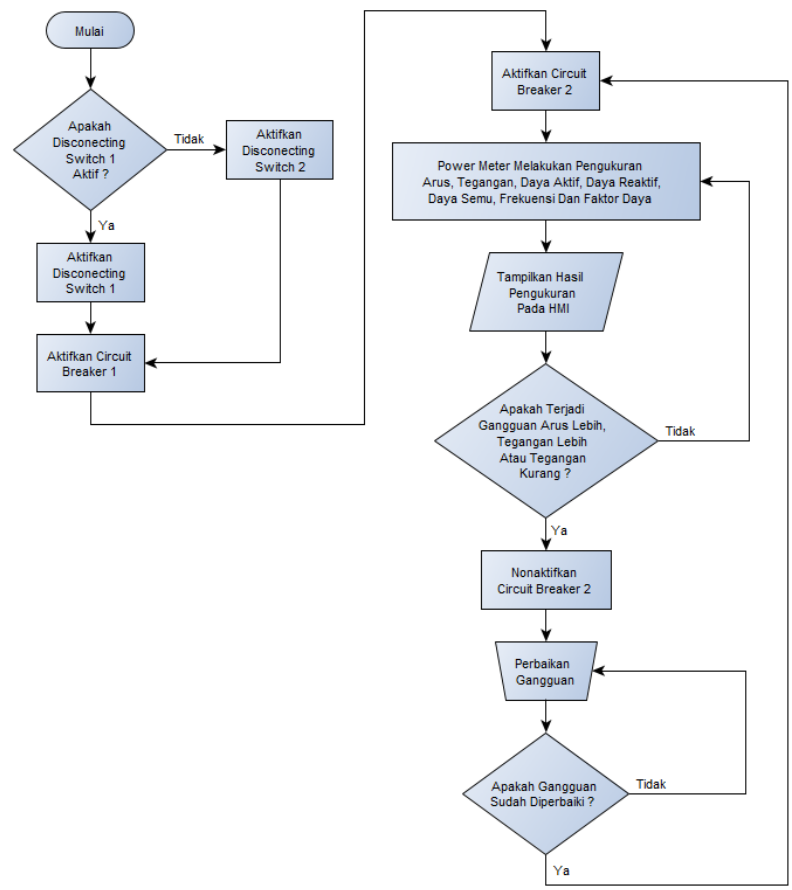

Gambar 2. Diagram Alir Sistem Kendali

\section{HASIL DAN PEMBAHASAN}

A. Bagian-bagian Simulator Plant Gardu Induk

Sistem dikatakan bekerja dengan baik apabila terjadi proses yang saling berkaitan antara bagian satu dengan lainnya. Setiap bagian memiliki fungsi masing-masing dan ISSN 2615-5788 Print (2615-7764)

\section{(O2020 JURNAL TEKNIK ELEKTRO DAN KOMPUTER TRIAC}

disatukan menjadi suatu sistem. Gambar 3 merupakan bagian-bagian dari simulator plant gardu induk.

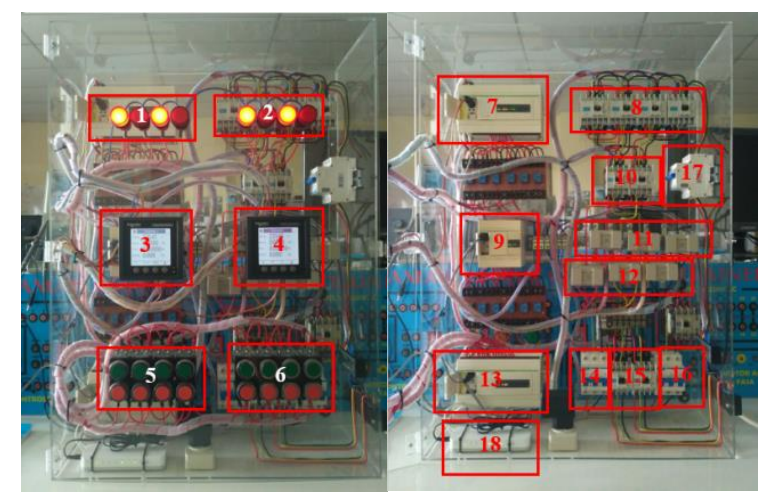

Gambar 3. Bagian-bagian Simulator Plant Gardu Induk

Keterangan:

1. Lampu Indikator Disconecting Switch dan Circuit Breaker

2. Lampu Indikator Disconecting Switch dan Circuit Breaker

3. Power Meter PM5350

4. Power Meter PM5350

5. Tombol ON-OFF Disconecting Switch dan Circuit Breaker

6. Tombol ON-OFF Disconecting Switch dan Circuit Breaker

7. PLC Twido TWDLCAE40DRF (PLC slave 1)

8. Disconecting Switch

9. PLC Twido TWDLCAA16DRF (PLC slave 2)

10. Circuit Breaker

11. Current Transformer 1

12. Current Transformer 2

13. PLC Twido TWDLCAE40DRF (PLC master)

14. MCB 3 Fasa

15. Circuit Breaker

16. MCB 3 Fasa

17. MCB 3 Fasa

18. Ethernet Hub

\section{B. Pengujian Komunikasi PLC Master-Slave}

\section{PLC Master Ke PLC Slave 1}

Pada pengujian ini bertujuan untuk mengetahui komunikasi pada PLC master ke PLC slave 1 dengan menggunakan software Twido Suite, komunikasi antara PLC master ke PLC slave 1 menggunakan modbus ethernet. Pada ladder diagram PLC master menggunakan fungsi macros comm yaitu C_WR1B, fungsi ini bertugas untuk menulis 1 bit pada jaringan modbus yang dikirim ke alamat PLC slave 1. 
Pada saat \% 10.0 atau \%M0 pada ladder diagram PLC master berubah keadaan dari NO ke NC (posisi aktif) fungsi C_WR1B langsung menulis 1 bit bernilai 1 (ON) pada jaringan modbus dan dikirim ke alamat \%M0 pada PLC slave 1, setelah data 1 bit yang bernilai 1 diterima oleh PLC slave 1 maka alamat \%M0 pada PLC slave 1 berubah keadaan dari NO ke NC (posisi aktif). Gambar 4 merupakan keadaan ladder diagram pada PLC master saat menulis 1 bit pada jaringan modbus dengan alamat pengiriman PLC slave 1, sedangkan Gambar 5 merupakan keadaan ladder diagram pada PLC slave 1 saat menerima data 1 bit dari PLC master.

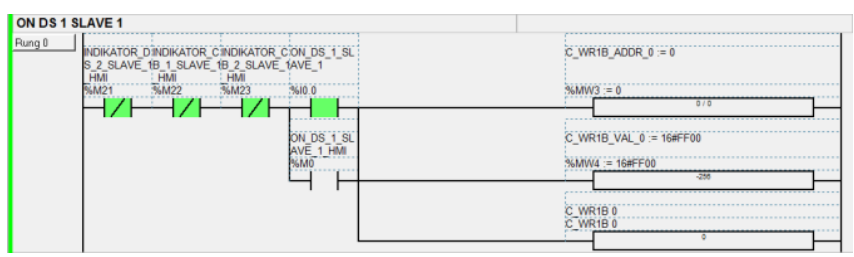

Gambar 4. Ladder diagram pada PLC master saat menulis 1 bit pada jaringan modbus dengan alamat

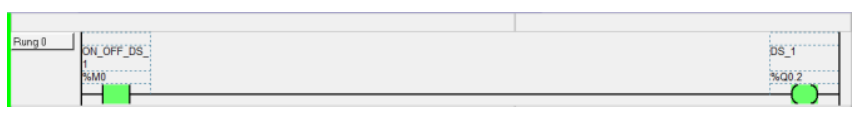

Gambar 5. Ladder diagram pada PLC slave 1 saat menerima data 1 bit dari PLC master

\section{PLC Master Ke PLC Slave 2}

Pada pengujian ini bertujuan untuk mengetahui komunikasi pada PLC master ke PLC slave 2 dengan menggunakan software Twido Suite, komunikasi antara PLC master ke PLC slave 2 mengunakan modbus serial RS485. Pada ladder diagram PLC master mengunakan fungsi macros comm yaitu C_WR1B, fungsi ini bertugas untuk menulis 1 bit pada jaringan modbus yang dikirim ke alamat PLC slave 1.

Pada saat \% 10.8 atau \%M8 pada ladder diagram PLC master berubah keadaan dari NO ke NC (posisi aktif) fungsi C_WR1B langsung menulis 1 bit bernilai 1 (ON) pada jaringan modbus dan dikirim ke alamat \%M0 pada PLC slave 2, setelah data 1 bit yang bernilai 1 diterima oleh PLC slave 2 maka alamat \%M0 pada PLC slave 2 berubah keadaan dari NO ke NC (posisi aktif). Gambar 6 merupakan keadaan ladder diagram pada PLC master saat menulis 1 bit pada jaringan modbus dengan alamat pengiriman PLC slave 2, sedangkan Gambar 7 merupakan keadaan ladder diagram pada PLC slave 2 saat saat menerima data 1 bit dari PLC master.

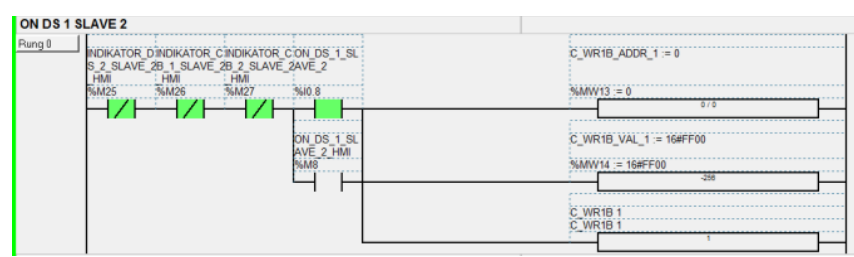

Gambar 6. Ladder diagram pada PLC master saat menulis 1 bit pada jaringan modbus dengan alamat pengiriman PLC slave 2

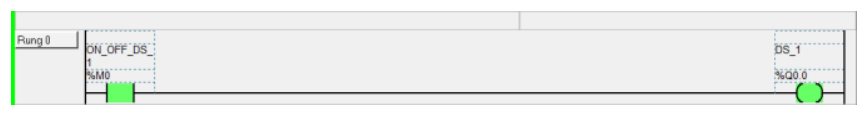

Gambar 7. Ladder diagram pada PLC slave 2 saat menerima data 1 bit dari PLC master

\section{Pengujian Sistem Keamanan SCADA}

Pada pengujian ini bertujuan untuk mengetahui sistem kemanan pada SCADA, pada sistem keamanan ini pengguna diharuskan memasukan nama pengguna dan kata sandi sebelum login/masuk ke sistem SCADA. Nama pengguna sistem sendiri dibagi menjadi dua yaitu supervisor dengan kata sandi "11111" dan operator dengan kata sandi "22222". Saat nama pengguna dan kata sandi yang dimasukan tidak sesuai maka tombol supervisor atau operator untuk login/masuk akan tetap di hidden, apabila nama pengguna dan kata sandi yang dimasukan sesuai maka tombol supervisor atau operator untuk login/masuk akan di unhidden. Gambar 8 merupakan tampilan saat memasukan nama pengguna dan kata sandi yang tidak sesuai, Gambar 9 merupakan tampilan saat memasukan nama pengguna supervisor dan kata sandi yang sesuai dan Gambar 10 merupakan tampilan saat memasukan nama pengguna operator dan kata sandi yang sesuai.

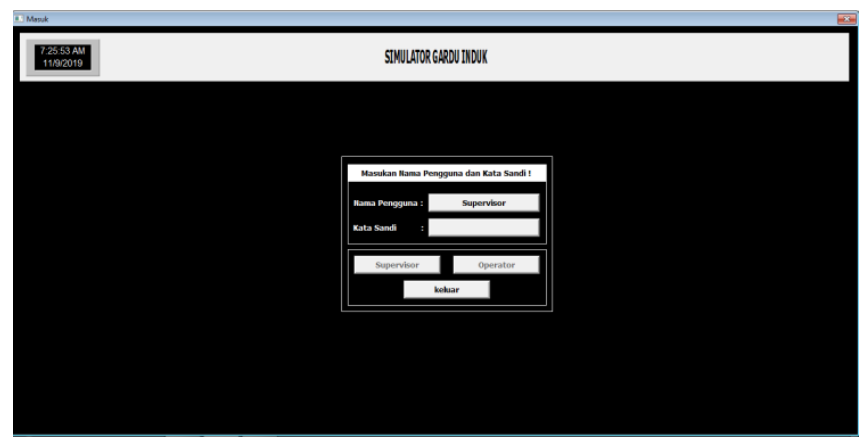

ISSN 2615-5788 Print (2615-7764) 
Gambar 8. Tampilan saat nama pengguna dan kata sandi tidak sesuai

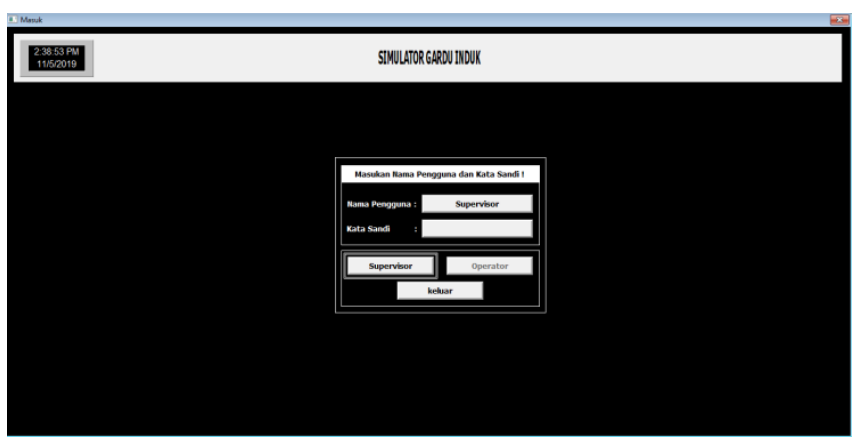

Gambar 9. Tampilan saat nama pengguna supervisor dan kata sandi sesuai

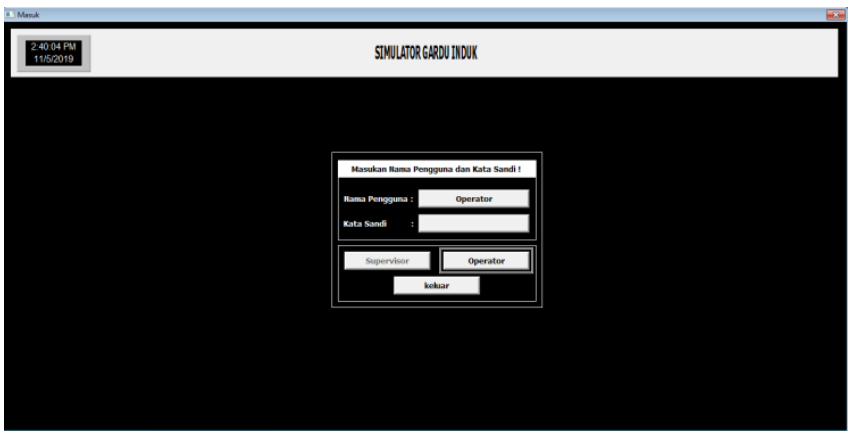

Gambar 10. Tampilan saat nama pengguna operator dan kata sandi sesuai

4. Pengujian Menampilkan Hasil Pengukuran Pada HMI

Pengujian ini bertujuan untuk mengetahui kinerja HMI sebagai media penampil hasil pengukuran besaran listrik pada simulator plant gardu induk. Pengujian dilakukan dengan memberi beban pada simulator plant gardu induk, lalu alat ukur Power Meter melakukan pengukuran arus, tegangan, daya aktif, daya reaktif, daya semu, frekuensi dan faktor daya. Hasil pengukuran Power Meter dibaca oleh PLC master. Gambar 11 merupakan hasil pembacaan nilai pengukuran Power Meter di PLC master.

\begin{tabular}{|c|c|c|c|c|}
\hline & Us & Address & Symbol & Current \\
\hline 11 & $\sqrt{v}$ & \%MF26 & NILAI_ARUS_R_S & 0.9257815 \\
\hline 2 I & $\mid \nabla$ & \%MF36 & NILAI_ARUS_S_S & 1.039063 \\
\hline 3 I & $\sqrt{2}$ & \%MF46 & NILAI_ARUS_T_S & 0.9843752 \\
\hline 4 & $\sqrt{\square}$ & \%MF56 & NILAI_TEGANGA & 219.0001 \\
\hline 5 & $\nabla$ & \%MF66 & NILAI_TEGANGA & 221.0001 \\
\hline 6 I & $\mid \nabla$ & \%MF76 & NILAI_TEGANGA & 217.0001 \\
\hline 7 I & $1 \sqrt{2}$ & \%MF86 & NILAI_TEGANGA & 378.0001 \\
\hline 8 & $1 \nabla$ & \%MF96 & NILAI_TEGANGA & 382.0001 \\
\hline 9 & $\sqrt{\nabla}$ & \%MF106 & NILAI_TEGANGA & 376.0001 \\
\hline 10 & $\square$ & \%MF116 & NILAI_DAYA_AKT & -0.1904297 \\
\hline 11 | & $\square$ & \%MF126 & NILAI_DAYA_REA & -0.6171877 \\
\hline 12 I & $\square$ & \%MF136 & NILAI_DAYA_SE & 0.6484377 \\
\hline 13 | & $\square$ & \%MF146 & NILAI_FREKUEN & 49.75002 \\
\hline 14 & $\square$ & \%MF156 & NILAI_FAKTOR_D & -0.2929689 \\
\hline 15 | & $\sqrt{\nabla}$ & \%MF166 & NILAI_ARUS_R_S & 0.730469 \\
\hline 16 | & $\sqrt{\square}$ & \%MF176 & NILAI_ARUS_S_S & 1.015625 \\
\hline 17 i & $\sqrt{\nabla}$ & \%MF186 & NILAI_ARUS_T_S & 1.007813 \\
\hline 18 & $\sqrt{\nabla}$ & \%MF196 & NILAI_TEGANGA & 218.0001 \\
\hline 19 | & $\sqrt{\nabla}$ & \%MF206 & NILAI_TEGANGA & 221.0001 \\
\hline 20 I & $\sqrt{\square}$ & \%MF216 & NLAI_TEGANGAN & 217.0001 \\
\hline 21 | & $\sqrt{\nabla}$ & \%MF226 & NILAI_TEGANGA & 380.0001 \\
\hline 22 I & $\sqrt{2}$ & \%MF236 & NILAI_TEGANGA & 382.0001 \\
\hline 23 | & $\sqrt{\square}$ & \%MF246 & NILAI_TEGANGA & 376.0001 \\
\hline 24 | & $\square$ & \%MF256 & NILAI_DAYA_AKT & -0.2236329 \\
\hline 25 i & $\square$ & \%MF266 & NILAI_DAYA_REA & -0.558594 \\
\hline 26 I & $\square$ & \%MF276 & NILAI_DAYA_SE & 0.6015627 \\
\hline 27 & $\square$ & \%MF286 & NILAI_FREKUEN & 50.00002 \\
\hline 28 i & & \%MF296 & NILAI_FAKTOR_D & -0.3710939 \\
\hline
\end{tabular}

Gambar 11. Hasil pembacaan nilai pengukuran Power Meter di PLC master

Setelah data pengukuran besaran listrik pada simulator plant gardu induk terbaca oleh PLC master, data pengukuran tersebut dibaca oleh KEPServerEX melalui tagtag. Nilai hasil pengukuran yang dibaca oleh KEPServerEX dapat dilihat pada Gambar 12 berikut.

\begin{tabular}{|c|c|c|c|c|c|}
\hline Item ID & Data Type & Value & Timestamp & Quality & Update Count \\
\hline OPLC.MASTER.A_ER_PM_3 & Float & 0.914063 & 12:43:54:986 & Good & 6 \\
\hline 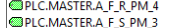 & $\begin{array}{l}\text { Float } \\
\text { Float }\end{array}$ & 0.726563 & $\begin{array}{ll}12: 43: 50: 821 \\
120: 4355: 571\end{array}$ & Good & ${ }^{2}$ \\
\hline 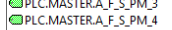 & $\begin{array}{l}\text { Float } \\
\text { Float }\end{array}$ & $\begin{array}{l}1.03906 \\
1.01563\end{array}$ & $\begin{array}{l}121: 43: 5655577 \\
1224: 50: 821\end{array}$ & $\begin{array}{l}\text { Good } \\
\text { Good }\end{array}$ & ${ }_{2}^{4}$ \\
\hline OPLC.MASTER.A_ET_PM__- & & & $\begin{array}{l}12: 43: 530: 8212 \\
12: 45: 517\end{array}$ & & \\
\hline DLC.MASTER.A.T.TPM-4 & $\begin{array}{l}\text { Float } \\
\text { Float }\end{array}$ & 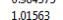 & 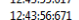 & Good & 5 \\
\hline OPLC.MASTER.D_APM_3 & Float & -0.191406 & $12: 43: 56: 593$ & Good & \\
\hline OPLC.MASTER.D_A_PM_4 & Float & -0.224609 & 12:43:5:54:924 & Good & 3 \\
\hline OPLC.MASTER.DR_PM_-3 & Float & -0.617188 & 12:43:50:837 & Good & 5 \\
\hline PILC.MASTER.D_R_PM_4 & Float & -0.558594 & 12:43:50:634 & Good & \\
\hline OPLC.MASTER.D_S_PM_3 & $\begin{array}{c}\text { Float } \\
\text { Float }\end{array}$ & 0.644531 & $\begin{array}{ll}12: 43: 50: 868 \\
\end{array}$ & Good & 4 \\
\hline 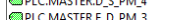 & $\begin{array}{l}\text { Float } \\
\text { cloat }\end{array}$ & 0.0003533 & 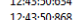 & Good & ${ }_{5}^{2}$ \\
\hline PPCMATSRE D PM & Float & 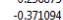 & 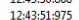 & Good & 3 \\
\hline DPLC.MASTER.F_PM_3- & Float & $\begin{array}{ll}50 & -0.571094 \\
50\end{array}$ & $\begin{array}{l}12: 44: 41,40: 036 \\
136\end{array}$ & Good & 1 \\
\hline OPLC.MASTER.EPM_4 & Float & 50 & 12:41:46:021 & Good & 1 \\
\hline DPLC.MASTER.TF F PM_ 3 & Float & 218 & 12:43:55:017 & Good & 5 \\
\hline OPLC.MASTER.T_E___PPM_4 & Float & 218 & 12:43:49:901 & Good & 5 \\
\hline OPLC.MASTRRT_TERS._PM_3 & Float & 378 & 12:43:54:425 & Good & 6 \\
\hline DPLCMASTERTTERRSPM_-4 & Float & 378 & 12:43:47:919 & Good & 4 \\
\hline PLLC.MASTERT_F___SPM_3 & $\begin{array}{l}\text { Float } \\
\text { Floats }\end{array}$ & ${ }^{221}$ & $\begin{array}{l}12: 44: 03: 941 \\
12: 403: 145\end{array}$ & Good & ${ }_{17}^{17}$ \\
\hline 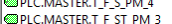 & $\begin{array}{l}\text { Float } \\
\text { Float }\end{array}$ & ${ }_{382}^{221}$ & $\begin{array}{l}12: 44403: 145 \\
1224: 2854\end{array}$ & $\begin{array}{l}\text { Good } \\
\text { Good }\end{array}$ & \\
\hline 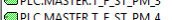 & & 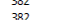 & 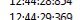 & Good & \\
\hline PPCMATRRT FT PM 3 & Float & 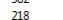 & 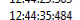 & Good & 9 \\
\hline DPLC.MASTERT.TFT PMM 4 & Float & 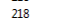 & 12:44:34:704 & Good & 19 \\
\hline DPLC.MASTER.T_F_TR_PM_3 & Float & 376 & 12:44:45:530 & Good & 16 \\
\hline OPLC.MASTERTTE_TRPM-4 & Float & 376 & 12:44:45:717 & Good & 14 \\
\hline
\end{tabular}

Gambar 12. Nilai hasil pengukuran yang dibaca oleh KEPServerEX

Nilai pengukuran yang dibaca oleh KEPServerEX melalui tag-tag, dibaca kembali oleh tag-tag yang dibuat di software SCADA Wonderware InTouch lalu ditampilkan pada HMI. Gambar 13 merupakan HMI yang menampilkan hasil pengukuran pada plant jalur Transformer 1, sedangkan

ISSN 2615-5788 Print (2615-7764) 
hasil pengukuran pada plant jalur Transformer 2 dapat dilihat pada Gambar 14.

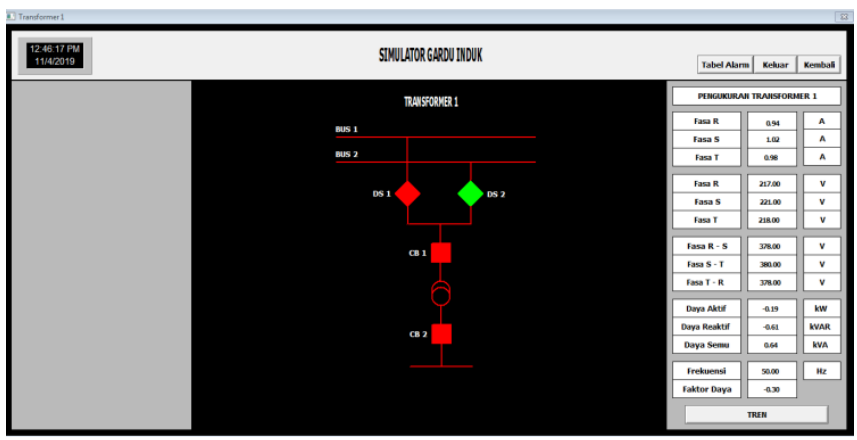

Gambar 13. HMI menampilkan hasil pengukuran pada jalur Transformer 1

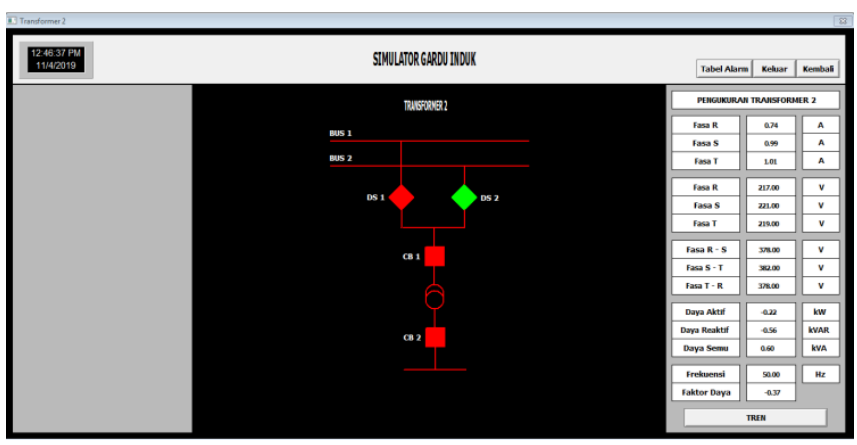

Gamabr 14. HMI menampilkan hasil pengukuran pada jalur Transformer 2

5. Pengujian Alarm Management

Pada pengujian ini bertujuan untuk mengetahui kinerja alarm management pada simulator sistem SCADA gardu induk. Pada sistem yang dibangun terdapat beberapa alarm yaitu alarm arus lebih, alarm tegangan kurang dan alarm tegangan lebih. Alarm akan muncul dan memberitahu kepada pengguna, serta mencatat jenis alarm yang tejadi pada tabel alarm di sistem SCADA ketika nilai pada pengukuran diatas setpoint untuk alarm arus dan tegangan lebih dan ketika nilai pengukuran dibawah setpoint untuk alarm tegangan kurang.

Pengujian alarm arus lebih dilakukan dengan cara memberikan beberapa beban pada simulator plant gardu induk sehingga arus yang mengalir pada plant akan melebihi setpoint, setpoint untuk alarm arus lebih nilainya 8 A. Saat arus yang mengalir lebih dari setpoint sistem SCADA akan menampilkan peringatan pada HMI dan mencatat jenis alarm yang terjadi pada tabel alarm. Gambar 15 merupakan peringatan pada HMI saat terjadi alarm dan Gambar 16 merupakan tampilan tabel alarm saat mencatat alarm arus lebih.

ISSN 2615-5788 Print (2615-7764)

(O2020 JURNAL TEKNIK ELEKTRO DAN KOMPUTER TRIAC

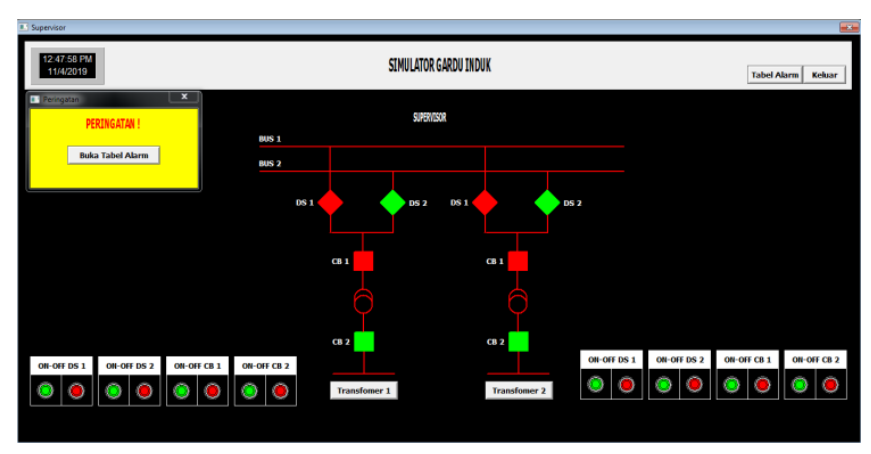

Gambar 15. HMI saat terjadi alarm

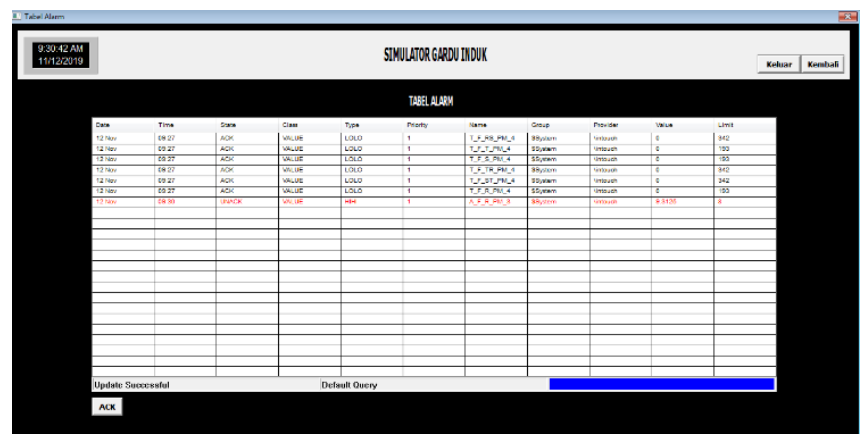

Gambar 16. HMI tabel alarm saat mencatat alarm arus lebih.

Pengujian alarm tegangan lebih dilakukan dengan cara memberikan nilai tegangan melebihi setpoint sistem, setpoint untuk tegangan lebih fasa L-N nilainya 242 volt dan setpoint untuk fasa L-L nilainya 418 volt. Saat tegangan yang mengalir lebih dari setpoint, sistem SCADA akan menampilkan peringatan pada HMI dan mencatat jenis alarm yang terjadi pada tabel alarm. Gambar 17 merupakan tampilan tabel alarm saat mencatat alarm tegangan lebih.

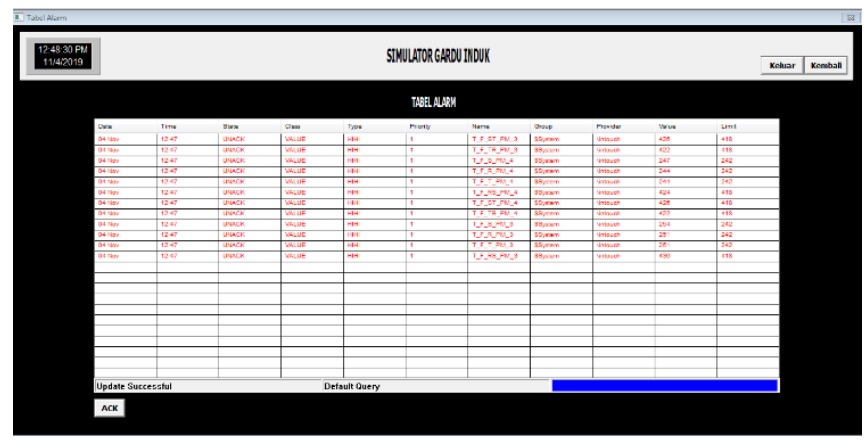

Gambar 17. HMI tabel alarm saat mencatat alarm tegangan lebih 
Pengujian alarm tegangan kurang dilakukan dengan cara memberikan nilai tegangan kurang dari setpoint sistem, setpoint untuk tegangan kurang fasa L-N nilainya 198 volt dan setpoint untuk fasa L-L nilainya 342 volt. Saat tegangan yang mengalir kurang dari setpoint, sistem SCADA akan menampilkan peringatan pada HMI dan mencatat jenis alarm yang terjadi pada tabel alarm. Gambar 18 merupakan tampilan tabel alarm saat mencatat alarm tegangan kurang.

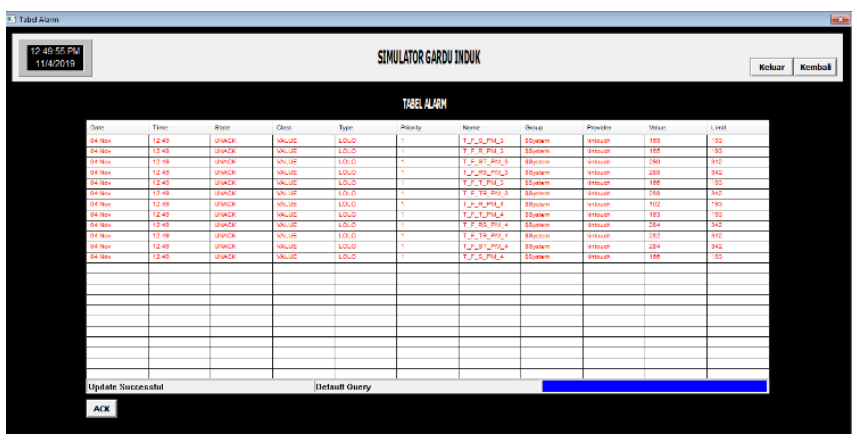

Gambar 18. HMI tabel alarm saat mencatat alarm tegangan kurang

6. Pengujian Data Logger

Pada pegujian data logger bertujuan untuk mengetahui kinerja database Microsoft Access sebagai data logger pengukuran besaran listrik pada simulator sistem SCADA gardu induk. Database Microsoft Access akan melakukan data logger dengan interval waktu 1 detik, jadi setiap 1 detik hasil pengukuran besaran-besaran listrik simulator plant gardu induk seperti arus, tegangan, daya aktif, daya reaktif, daya semu, frekuensi dan faktor daya akan disimpan di dalam database Micrososft Access. Gambar 19 merupakan hasil data logger jalur Transformer 1 pada database Microsoft Access dan Gambar 20 merupakan hasil data logger jalur Transformer 2 pada database Microsoft Access.

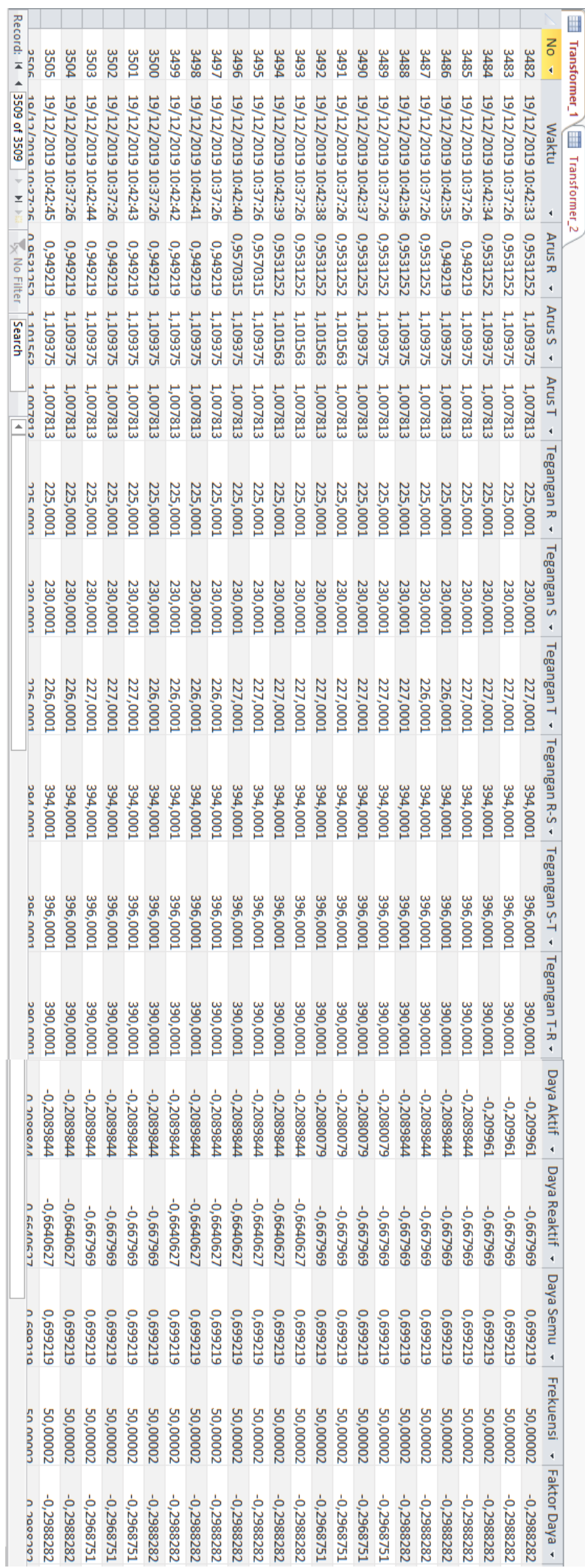

Gambar 19. Data logger jalur Transformer 1 pada database Micrsoft Access

ISSN 2615-5788 Print (2615-7764)

C2020 JURNAL TEKNIK ELEKTRO DAN KOMPUTER TRIAC

Vol. 7 No. 1 Tahun 2020 


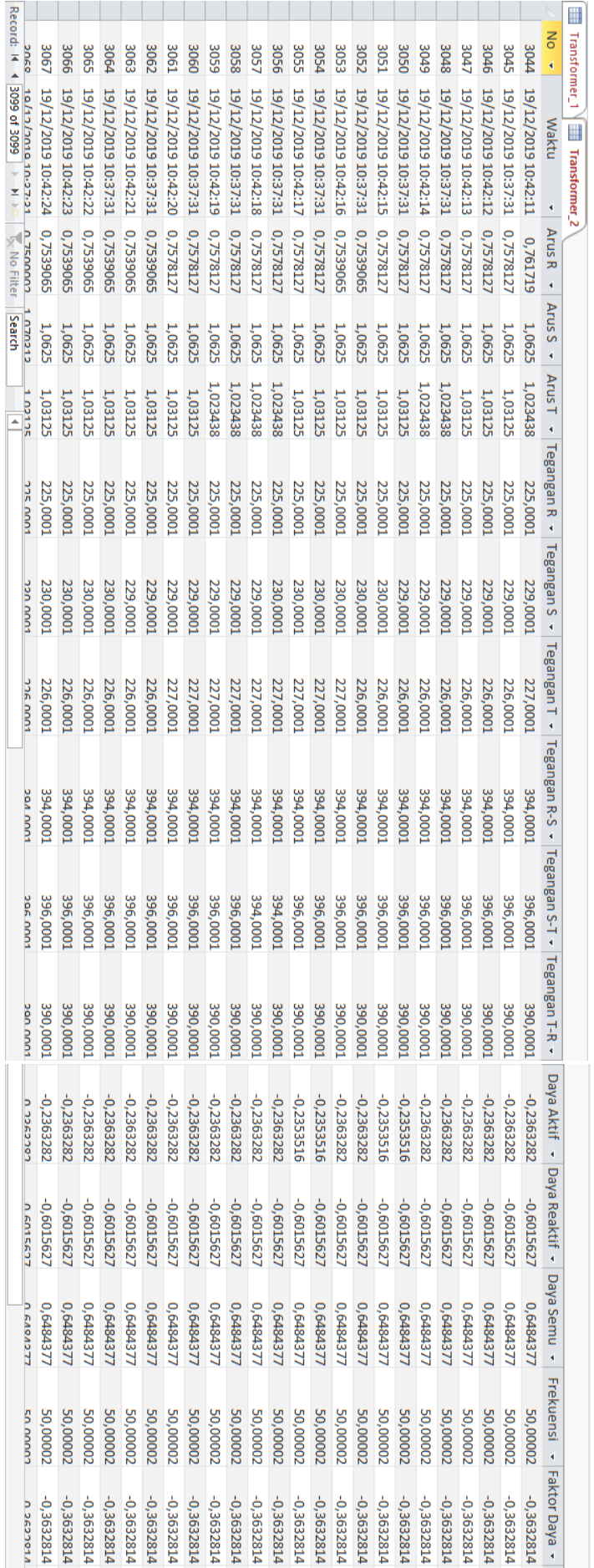

Gambar 20. Data logger jalur

Transformer 2 pada database Micrsoft Access

\section{KeSIMPULAN}

Berdasarkan hasil dari perancangan dan pengujian simulator sistem SCADA gardu induk dapat disimpulkan sebagai berikut:

1. Penggunaan memori pada ladder diagram mampu melakukan proses monitoring dan kontrol yang dapat dibaca oleh sistem SCADA.

2. Penggunaan software SCADA Wonderware InTouch dapat memvisualisasikan plant yang dikontrol dan menampilkan hasil pengukuran simulator plant gardu induk pada HMI.

3. PLC Twido TWDLCAE40DRF dapat difungsikan sebagai PLC master pada simulator sistem SCADA gardu induk.

4. PLC Twido TWDLCAE40DRF dan PLC Twido TWDLCAA16DRF dapat difungsikan sebagai PLC slave pada simulator sistem SCADA gardu induk.

5. Management alarm yang ada pada sistem akan secara otomatis menulis pada tabel alarm yang tersedia pada sistem SCADA jika terjadi gangguan pada plant.

6. Data logger hasil pengukuran besaran listrik simulator plant gardu induk disimpan di dalam sebuah database Microsoft Access.

\section{DAFTAR PUSTAKA}

[1] Andi, A. Priatmadja, R. 2015. Rancang Bangun Protocol Modbus Pada KWH Meter Elektronik Tipe ION 8600 Untuk Memonitor Besaran Energi Listrik Trafo Dengan Menggunakan Aplikasi Citect SCADA. Jurnal Teknologi Elektro, Universitas Mercu Buana, Vol.6 No.1, Januari 2015 ISSN: 2086-9479.

[2] Aniza Z, N. 2014. Perancangan Human Machine Interface Berbasis SCADA Pada PT. PLN (Persero) Unit Pengatur Beban (UPB) SUMBANGTENG. Program Studi Sistem Komputer, Fakultas Teknologi Informasi, Universitas Andalas Padang. Bharata, H, K. 2019. Pemanfaatan Jaringan LAN Untuk Integrasi SCADA Dengan Aplikasi Human Machine Interface Pada Sistem Monitoring Produksi. STMIK Binasaleh, Jurnal Gerbang, Vol. 9, No. 2, Agustus 2019.

[3] Hamdani. 2017. Audit Energi Sistem Kelistrikan Gedung Politeknik Negeri Ujung Pandang Menggunakan SCADA Sebagai Instrumen Pengukuran Permanen. Jurusan Teknik Elektro. Politeknik Negeri Ujung Pandang, Prosiding Seminar Hasil Penelitian (SNP2M) 2017 (pp.171-177).

[4] Irwan, H, E. Nurhadi, S. 2018. Studi Perencanaan Prototipe Sistem Otomasi Metering Gardu Induk Menggunakan Konsep Human Machine Interface. Jurnal ELTEK, Vol 16 No 01, April 2018 ISSN 1693-4024.

[5] Vignesh, T. Kirubakaran, J. 2015. Automation Based Power Transmission Control Station Using PLC and SCADA. IJISETInternational Journal of Innovative Science, Engineering \& Technology, Vol.2 Issue 2, February 2015. 